\title{
Bangladesh Journal of Orthodontics and Dentofacial Orthopedics Official Publication of Bangladesh Orthodontic Society.
}

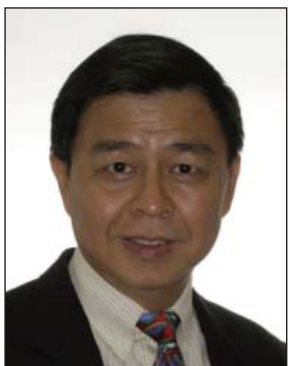

Message

President

APOS.

Dear Dr Hossain,

"I am happy and proud to see a member of the Asian Pacific Orthodontic Society, the Bangladesh Orthodontic Society (BOS), took the plunge to start the publishing of the Bangladesh Journal of Orthodontics and Dentofacial Orthopedic. It speaks very well for the leadership of BOS especially the Editorial Committee headed by Prof. Md. Zakir Hossain.

Editor -in-chief, Prof Hossain received his $\mathrm{PhD}$ from the University of Hiroshima, Japan. His education from Japan has made him an outstanding regional leader in orthodontic education. With his able leadership, I am sure the quality of orthodontic education, research and clinical expertise in Bangladesh will continue to improve at a very fast pace.

May I also congratulate the President of Bangladesh Orthodontic Society, Prof.

(Dr.) Mohammad Emadul Haq for his excellent leadership.

Warmest Regards

Dr. Loh Kai-Woh

President

APOS. 